\title{
Hegemony and the Chinese Non-Interference Policy in Africa-A Friend or Foe?
}

\author{
Shuresh Moradi \\ Tsinghua School of Law, Beijing, China \\ Email: Shuresh.mor@gmail.com
}

How to cite this paper: Moradi, S. (2019). Hegemony and the Chinese Non-Interference Policy in Africa-A Friend or Foe? Chinese Studies, 8, 156-173.

https://doi.org/10.4236/chnstd.2019.83013

Received: July 24, 2019

Accepted: August 25, 2019

Published: August 28, 2019

Copyright $\odot 2019$ by author(s) and Scientific Research Publishing Inc. This work is licensed under the Creative Commons Attribution International License (CC BY 4.0).

http://creativecommons.org/licenses/by/4.0/

\begin{abstract}
China is Africa's largest trade partner and enjoys deep political ties with many African states. However, the strength and depth of these relations are not reflected in China's contribution to African peace and security. This research therefore unpacks the reason for such a discrepancy by placing non-interference at the centre of the question. The working hypotheses for this paper are that with regard to the resolution of African conflicts, the impact of China's policy of non-interference is twofold. Firstly, the sovereignty of African states is bolstered as China refrains from interfering in the internal affairs of the respective state. Secondly, China's rigid interpretation of non-interference becomes an obstacle preventing China from playing an active role in the resolution of African conflict. The hypothesis will be tested by means of a comparative case study by contrasting how Chinese non-interference has impacted the respective peace processes in Zimbabwe. What is evident from an evaluation of these cases is that cooperation with key regional organisations is sorely lacking in China's approach to the promotion of peace in Africa. This paper, thus aims, to offer an alternative framework in which China can play an active and constructive role yet still abiding by the founding principles of non-interference.
\end{abstract}

\section{Keywords}

Hegemony, Non-Interference Policy, Africa, Sino-African Relations

\section{Introduction}

This paper will unpack the role played by China in the Africa peace processes and security mechanisms. The author undertakes to examine China's impact on the promotion of peace within Africa. An undertaking of this nature necessarily demands one critique of Chinese policy of non-interference as this is a staunch 
pillar of Chinese foreign policy in relation to the domestic affair of other countries. While always championing and encouraging peace, China has by and large sought to remove itself from any direct interventions into the internal conflicts of states. In order to fully understand the significance and impact of non-interference, an analysis of the ideological foundations and political rationale of the policy will be essential. Once this context and structure have been established, this paper will draw attention to how the policy of non-interference has manifested itself in terms of actual engagement with African countries. The impact of the policy on peace and security will be assessed and evaluated.

The argument of this paper will put forward is that the impact of the policy of non-interference is twofold. Firstly, non-interference aligned China to African countries by respecting their sovereignty and allowing them the opportunity to resolve their internal conflicts. This resulted in China gaining trust, credibility and a competitive advantage as a strategic partner from African states. Secondly, the policy of non-interference in its rigid interpretation and implementation, has become an obstacle which prevents China from playing a truly active and effective role in promoting peace. Once the reasons for this assertion have been comprehensively explained, this thesis will explore alternative cooperation models and policy in which China can engage to positively impact peace. In other words, the paper will attempt to map out alternative peace and security policy and mechanisms which would allow China to continue to abide by the policy of non-interference and yet play a much more substantial role in the promotion of African peace.

\section{Delimitation}

This paper will use a definition of conflict which encompasses a broad spectrum of circumstances. Under the African context many varying conditions give rise to violent eventualities. However, for the sake of this paper only conflicts that have politico-economic foundations and repercussion will be examined. It is important that the types of conflicts analysed are conflicts which have an impact on the geopolitical landscape of a country, and subsequently demand the attention of the wider African community as well as the international community at large. The specific type of conflicts that will be taken into consideration in this paper consist of: inter-state wars and inter-state conflict; intra-state conflicts such as civil wars and ethno-political disputes; violent uprisings and insubordination by civilians; ideological conflicts. These can be broadly categorised as inter-state conflict, intra-state conflict and political violence.

For the sake of this paper, only African conflicts that occurred between 2000 and 2015 will be considered. The reason the year 2000 has been selected as a starting point is because from this period there was a marked shift in China Africa relations. If one surveys the economic relations between China and Africa, they can be roughly divided into three periods. The first period is from 1949-1979. During this period, a political agenda was the main driving force behind China's economic engagements in Africa. This agenda was to build diplo- 
matic relations by providing economic assistance to newly independent African countries to support the anti-imperial and anti-colonial struggle that was being waged by many African countries. Moreover, China also wanted to garner support for the People's Republic of China internationally (Yu, 2014).

The year 2000 onwards China-Africa relations experienced increasing institutionalisation. This process of institutionalisation was encapsulated by the establishment of the Forum for China-Africa Cooperation (FOCAC) (Kambudzi, 2013). The establishment of FOCAC is widely viewed to be the most critical point in the recent development of China Africa relations. The establishment of FOCAS and the corresponding Chinese willingness and enthusiasm in the process demonstrated an elevation in the magnitude and substance of China-Africa engagements.

\section{Factors Determining China's Role in African Peacebuilding}

There are three main factors influencing China to increase its role in terms of African peace. The first is China's position in the current international climate. The second is that a stable and peaceful Africa would continue and add credible weight to China's conception of a harmonious world. The very serious security concerns in Africa have transitioned from being an indirect threat to China to being a very real threat. As Chinese economic interests in Africa deepen and expand, so does the need to protect and secure these economic interests.

Firstly, the motivation for China to increase its role in African peace and security is born from China's current position in the international political system. China's status as a global power has risen dramatically in correspondence to its position as the world's second largest economy. A narrative gaining increasing acceptance is that, because of China's global clout, it should begin to take on more international responsibility. Yu and Wang argue one of the ways in which China can achieve this is through providing more international public goods. They argue strongly that international security is one of the public goods that should command China's attention (Yu \& Wang, 2008). The obligation China has to positively contribute to Africa's security is not only with respect to international security, they contend, but also because of China's commitments to the continent's economic development of Africa as a partner in the global South and a member of the global community (Yu \& Wang, 2008).

The idea of a safe, secure and peaceful international community fits directly into the Chinese conception of a "harmonious world". It is essential for China's own legitimacy for it to position itself at the centre of this pursuit for international peace and security. China would like to be viewed as a responsible and reliable member of the international community (Shi, 2008). In 2005, speaking in reference to China's role in the promotion of international peace and the necessary development thereof, Foreign Minister Li Zhaoxing stated, "China has quickly realised that Africa will become an important stage where its imagine as 
a responsible global actor is forged." (Speers-Mears, 2011). In this light of the promotion of a harmonious world, China's international image has been significantly tarnished by its engagements in Africa with regard to peace and security. China's continued interactions with the ruling regimes of countries in the midst of violent political insecurity were widely and harshly criticised. The accusation was that these engagements were contrary to acting as a responsible power. China was furthermore accused of being indifferent to the internal conflicts of the African countries.

China's trade with Africa has grown at a tremendous rapid rate in recent years. In 2000 Sino-Africa trade had reached $\$ 10$ billion, having only totalled $\$ 121$ million 50 years earlier. By 2009 China had surpassed the United States as Africa's largest trade partner. In 2012 this trade had experienced mammoth growth and amounts to $\$ 198.5$ billion (The Economist, 2013, http://www.economist.com/news/middle-east-and-africa/21574012-chinese-trad e-africa-keeps-growing-fears-neocolonialism-are-overdone-more). From a foreign direct investment (FDI) point of view, Sino-African relations have also shown considerable growth. Between 2007 and 2008 FDI grown from $\$ 1.57$ billion to $\$ 5.49$ billion. This clearly illustrates that China is deeply entrenched in economic engagements in Africa.

China heavily relies on natural resourced to propel its economic development forward. Africa's abundance of minerals, energy reserves and raw material contributes greatly to this effect. More than $80 \%$ of China's imports from Africa consist of raw materials and natural resourced. In fact, Africa is now China's second largest supplier of crude oil, behind the Middle East (Yu, 2014). As China mainly exports manufactured goods to Africa, it also views Africa as holding massive market potential. African market acts as a growth area for Chinese investments and goods. This is critical for China as they seek to maintain sufficiently high domestic growth rates through engagements with new global markets. However, development and subsequent prosperity are crucial elements which will enable Africa to be able to fulfil its potential as a key economic partner for China. This prosperity is severely handicapped by the insecurity and violence that continues to plague Africa.

\section{Ideological Framework}

China's implementation of non-interference has significantly boosted African sovereignty. By refraining from interfering in the internal affairs of African states, and affording them the opportunity to take agency over their own security processes, China has enshrined the idea of an independent and sovereign Africa. China, in attempt to uphold the idea of sovereignty has almost exclusively interacted in a state-to-state fashion, at times even when the situation demanded a more regional approach. This can be explained by the conception of a "Proxy-hegemonic" relationship. It is by unpacking this theory and relating it to China's interactions with regional authorities such as South Africa will provide 
important insight into the security dynamics of Sino-African relations. Hegemonic stability theory suggests that the international system is more likely to maintain its stability when a sing nation-state is a hegemon (Keohane, 1996). The idea power which a hegemon exerts is a much more layered and complex concept than typical international relations of theories of realism have defines it as. Furthermore, at the regional level, there are actors outside of that particular region who may nonetheless hold power and seek to use their power of influence conditions within the region. Therefore, any regional balance of power and subsequent stability, can be altered by an external actor (Moller, 2009). Within an African context where no outright hegemon exists, states will begin to form coalitions and alliances in an attempt to consolidate any weakness of limitations. It is clear not that not only is power, even hegemonic power, relative but it can also be shared (Gill, 1993).

There are three manners in which hegemony can be constructed ${ }^{1}$. The concept most pertinent to this research, is so called "proxy hegemony" which would be a delegated hegemony bridging the international with the regional in a pseudo-hierarchical fashion. The international hegemony would delegate its hegemonic status to a great power on the regional scale (Moller, 2009).

Hegemony tends to insinuate negative connotations as our ideas of a powerful state tend to involve domination and coercion. But coercive and imperial means of exerting power are no longer tolerable in the modern international political climate. Modern hegemony is based on principles of legitimacy, consent and shared values. Hegemons are regime drivers, seeking to incorporate their own interests, by means of norms and values into regimes. This is all striven towards in the hope of forming a community of actors sharing the same fundamental ideas and goals (Keohane, 1982).

In order to prove this conclusively, a number of assumptions must be elaborated on. The first assumption is that China indeed has a major role to play in combatting the African security crisis, and thus should be taking on more responsibility. Implicit in this claim is an assertion that China, more so than other external actors, is best positioned to make a positive impact to the pace and security landscape in Africa. The motivation behind this assertion is the shared history of anti-colonial and anti-imperial struggles, which subsequently led to mutual ideological developments has led to a deep understanding and respect between China and Africa.

As one its central pillars, the policy of non-interference enshrines the respect for the national sovereignty of state. By a means of a narrow interpretation of the policy of non-interference, an exaggerated emphasis has been placed in state

${ }^{1}$ The Second conception is "Bigemony" or condominium which refers to a partnership between two great powers who have an approximately equal stats in terms of power. Throughout history examples of this have included US-German coalitions and US-Japan coalitions. The third conception is referred to as "Trigemony". This involves three powers pursuing trilateral collaborative venture. It can also take the shape of more than three actors, in which case it would simply become a group or multilateral hegemony. The "Concert of Europe" and the G8 are such examples. 
sovereignty to the extent that it has resulted in China engaging with Africa in a manner which is heavily state-centric. While this has undoubtedly tremendous implicit impact on bilateral state-to-state relations between China and African countries, is has occurred at the neglect of engagement with key non-state actors. Such as the African Union, which has assumed a supra-national authority on the continent, as well as the Regional Economic Communities such as ECOWAS and ECCAS. The importance of these regional and sub-regional organisations stems not only from their strategic importance in tackling African insecurity, but also from the monumental contributions these organisations make to the long-held aspirations of African integration.

\section{Proponents of Non-Interference}

Much of the championing of non-interference is rooted in a firm opposition to the liberal peace building methods which have been historically used to combat conflict in Africa. The policy of non-interference, as presented by scholars such as Zhao Lei and Liu Hui, captures four central ideological tenants. These tenants serve as a distinct departure from liberal peace building mechanisms and yet, argue the scholars, still provide a robust framework from which to promote peace in Africa. The first of the tenants is the idea that stability, development and harmony is a more attractive option for Africa than democratic freedoms linked to market economics. The assertion being made here is that the importance of political stability far outweighs holding elections. Peace is not seen to be contingent on democratic principles. Rather it is seen as the outcome of long-term development.

The second, and perhaps most widely applauded feature of China's approach to conflict resolution within Africa is the insistence that indigenous African solutions should be identified and pursued. China maintains that African should take ownership of the resolution process and tailor each solution according to their particular circumstance. It is firmly contended by China that any responsibility for resolving conflict or the subsequent reconstruction and development process should be held by the host state. Part of the justification behind this view is that taking ownership and agency over this resolution process directly contributes to the long-term capabilities and effectiveness.

The third aspect of China's stance on peace and security is the assertion that economics have a much more important role to play than political or military interventions. In China-Africa Relations-Governance, Peace and Security, Berhe and $\mathrm{Lu}$ stress that, "An alternative modality is presented in which China perceived peace as a 'historical inevitability' to materialise after dealing with developmental challenges." (Berhe \& Liu, 2013). Scholars of this inclination argue that basic needs such as food, security, housing and freedom of poverty should take precedence over liberal democratic ideals. Furthermore, emphasis should be placed on the infrastructural requirements needed for the economic acceleration in post conflict reconstruction.

Lastly, state sovereignty and the idea that this sovereignty is supreme, are the 
fourth tenant. Some Chinese scholars such as Li Anshan urge that developing countries view state sovereignty as vital because they have learned from historical experience that sovereignty is absolutely necessary to insulate them from the interference and interventions of external powers. Li proffers that the Western agenda of human rights protection is itself a state backed apparatus (Li, 2007). It is therefore in the interest of China and Africa to protect and enshrine state sovereignty so as to protect their citizens from unwanted external advanced and create fertile ground for internal political change and progression to take place.

It has been argued by some Chinese scholars that the ideological underpinnings, both historically and at present, play a crucial role in determining the nature of China-Africa relation (Li, 2005, 2007, 2011; Liu, 2008, 2010; Pan, 2011; He, 2006, 2007, 2008, 2009, 2010). The strong ideological commonality and understanding is what distinguished Africa's engagement with China from that of Africa's engagement with the more developed countries of the world such as the US and countries within the EU. While the historical foundations and interactions of states do not necessarily reflect or determine future engagements, it is worth exploring how history has shaped China-Africa relations. Li Anshan contends that this historical understanding affords China and Africa greater respect for each other's sovereignty and a greater sense of true understanding (Li, 2007).

By linking its foreign policy with its ideological position China's Africa diplomacy has been defined by Beijing's own ideological ideas. Li traces China's ideological development and how this impacted their engagement with Africa. China had initially positioned itself as a champion of the struggle against colonialism and imperialism. Having itself battled against British and Japanese imperialism; this shared colonial history now plays an important role in the shaping of China's Africa policy. By referencing China's diplomacy during the mid-1960's when China adopted an ultra-leftist approach, he argues that many scholars perceived this as China promoting a global idea of Maoism. This resulted in China seeking to "export revolution" to Africa (Li, 2007). This policy received much opposition among African leaders. Ian Taylor and Scarlett Cornelissen highlight how prevalent Chinese ideology of the time is in the policy making process towards Africa. To emphasis the point they show how this slogan of "exporting revolution" was ended towards the end of the 1960's when it was no longer in line with China's ideological position (Cornelissen \& Taylor, 2000).

The $12^{\text {th }}$ CPC Assembly was a turning point in China-Africa relations and can arguably be seen to have shaped the engagements that we witness today. Li argues that there were two ideological shifts decided upon that came to define China-Africa relations. The first of these was that China made the decision to place much greater emphasis on its own economic development. The second of these was that China would pursue an independent and peaceful foreign policy (Li, 2007). These two strategic elements had definite and long-lasting repercussions for China's policy toward Africa. If one looks at the first element, this intentional and concentrated focus on domestic economic development has come to characterise the model China thinks Africa should be pursuing. 
China has completely refrained from committing itself to any political or military intervention which could be perceived to be directly affecting domestic peace processes of African states in any way. They 12th CPC National Assembly instituted principles which encapsulated China's state to state political relationships (The Description of the 12th CPC Assembly, http://www.people.com.cn/GB/shizheng/252/5089/5104/5276/20010429/467489. html). These principles, which Taylor and Cornelissen argue are driving forces in China-Africa diplomacy are: mutual respect, complete equality, non-interference in the internal affairs of other and independence (Cornelissen \& Taylor, 2000).

Since these defining elements of Chinese foreign policy were introduced, policies might have changed but the underlying principles have remained intact. This is due to China's own history when it comes to foreign powers interfering in its internal affairs. It is these violations of China's sovereignty and intrusion into its domestic affairs that has led China to adopt such a steadfast and resolute approach when dealing with Africa. Since China and Africa have both experienced colonial oppressions, this shared experience motivates the ideas of sovereignty and equality which the two-place great emphasis on in their relations with one another (Li, 2007).

\section{Revision of Non-Interference}

China finds itself in a precarious position with regards to its non-interference policy. Many scholars argue that by continuing to simply implement it strictly, it risks condemnation from the international community for what could be perceived as a cold indifference to the socio-political perils of African countries-many of whom China has entrenched economic ties with (Alden \& Large 2011, 2015; Askouri, 2007; Large, 2008; Speers-Mears, 2011; Kuo, 2012). However, by aligning itself with Western-led interventionist policies China would be betraying the spirit and founding principles of its own foreign policy and those captured in the 12th CPC National Assembly. In essence, it would be betraying the global South. It is therefore imperative that China find alternative means to maintain its international legitimacy. Hybrid policies such as creative involvement-as coined by Wang Yizhou - and constructive intervention-as named by $\mathrm{Lu}$-are perfectly suited to remedy this dilemma. Wang described creative involvement as a new proactive policy in which China engages more frequently and more enthusiastically in international conflicts. It focuses on improving the skills on all Chinese office of foreign affairs to better mediate and cope with international issues. It fundamentally hinges on three principles, international legitimacy through the UN, invitation of host country and regional institutions; cautious deliberation of China's core interests in line with its capabilities; diplomatic meditation and economic assistance (military force only exceptionally used as a deterrent) (Beijing Review, 2012, http://www.bjreview.com.cn/world/txt/2012-03/05/content_439626_2.htm).

Constructive intervention, $\mathrm{Lu}$ argues, consists of two concepts. The first is the actual intervention. This, quite simply urges China to get involved-to engage 
with countries in need of their assistance (Lu, 2013). Much of the criticism levelled against China in relation to its contribution to African peace, has been that it is simply not active enough. The critique emphasises that non-interference should not be used as a means to excuse China from responsible engagement. The second concept regards the nature of this intervention. $\mathrm{Lu}$ insists that it must be constructive, always positive. China should seek to promote peace talks, remain neutral and maintain respect, equality and sovereignty. This would be implemented by means of mediation offices led by Special Envoys, support to and cooperation with the UN structure, and mediation programmes of the regional organisations ( $\mathrm{Lu}, 2013)$.

It is clear that this new concept does not have to infringe on abiding by noninterference. The charge that scholars such as $\mathrm{Lu}$ and Wang put forward to China is to not hide behind the veil of non-interference. While acknowledging the virtues of the policy, the scholars clearly envision much room for rethinking and revision of the implementation of the policy. It is not the policy itself that is flawed, but rather the strict interpretation and implementation that has prevented China from acting to its full potential in areas of conflict.

\section{Case Study-Zimbabwe}

To further articulate the theoretical arguments laid out above the paper will undertake a qualitative case study. The case study intends to compare and contrast the peacekeeping and peacebuilding mechanisms put into effect in one distinct case. China-South Africa cooperation will be magnified during the investigation of this conflict resolution process.

What this case study intends to investigate is how the peace measures were decided upon and implemented. The key variables the case study will be examining are "revision of rigid non-interference" from China's perspective and Pan-Africanism (measured by the level of regional cohesion and the prominence of regional institutions and authorities). The case study will survey the role these factors played in the peace process and how this contributed to the resolution, or failure thereof, of the conflict.

\section{Context to Conflict}

The year 2000-2008 brought about an intense period of political violence in Zimbabwe. Much of the conflict stemmed from land disputes and election related clashes. What is most pertinent to this thesis is the pre and post-election violence that took place around the 2008 elections. The issue of land ownership has been a hotly contested issue in Zimbabwe since the country was a British colony. During Zimbabwe's colonial period, both under British colonial rule and the white minority government that settled in Zimbabwe and unilaterally declared its independence from Britain, the considerably majority of the arable land was seized by the white Rhodesians. The black population of Zimbabwe were left to make do with what was referred to as "tribal reserves" (Human Rights Watch, 2002). Zimbabwe battled through a major civil war for its liberation and land was one of the core issues at hand. Eventually the British govern- 
ment and the Zimbabwean liberation organisations negotiated their way to a settlement referred to as the Lancaster House Agreement. This laid the foundation for Zimbabwe's first democratic general elections, which were duly won by the Zimbabwe African National Union-Patriotic Front (ZANU-PF), with Robert Mugabe as their president.

The resounding victory of the Mugabe-led ZANU-PF did not solve the land issue as the new government was prohibited from doing so by the Sunset Clauses of the Lancaster House Agreement. These clauses protected the ownership of white land ownership for the first ten years of Zimbabwe's independence. Land distribution, in the event that it did take place, would only be conducted on the condition of "willing buyer, willing seller" ("Zimbabwe, Profile-Timeline", http://www.bbc.com/news/world-africa-14113618). From the Lancaster House Agreement in 1990, the Zimbabwean government began to implement increasingly progressive land redistribution policies. These policies culminated in the radical and violent implementation of the Fast Track Land Reform programme of 2000. The programme aimed to remove land from the minority of white farmers who still controlled vast shared of the agricultural land, and redistribute it to poor and middle-income black Zimbabweans who owned no land (Human Rights Watch, 2002).

The Fact Track Land redistribution programme gave rise to widespread conflict and instability. Serious acts of violence were carried out against white farm owners and their farm workers, who were predominantly poor black Zimbabweans. These occupied farms were then used as bases and camps from which to stage further attacks on surrounding farms. These reprehensible acts of violence were committed mainly by ZANU-PF militia. These violent occupations of farms brought about numerous human rights violations, including torture, rape, abductions and disappearances, and even extra-judicial murders. Tony Reeler claims that Zimbabwe was subjected to gross human rights violations on an epidemic scale. He argues that Zimbabwe had become a version of a pariah state (Reeler, 2008). The state-sponsored violence persisted throughout the early 2000s into 2005, where it peaked with the brutal Operation Murambatsvina. On 19 May 2005 Zimbabwean police infiltrated the suburbs of Harare and Chitungwiza and demolished what they termed "illegal structures". The destruction of people's private dwellings spread throughout Zimbabwe rapidly-within a month, there was a reported 800,000 people that had been displace (UN Habitat, 2005). Not only were people displaced on an immense scale, but theft, destruction of property and grave violations of human rights were all prevalent. The Oxford Pro Bono Publico group go as far as to label Operation Murambatsvina as a crime against humanity. The rounds used for this justification are that the manner and the size in which the Operation was conducted resulted in a systematic and vast attack on the Zimbabwean civilian population. Moreover, it was concluded by the group that the Operation and its terrible consequences were the direct result of a State policy and State directives (Oxford Pro Bono Publico Group, 2005). 
The 2008 elections brought even more instability to the Zimbabwean socio-political climate. The Movement for Democratic Change, headed by Morgan Tsvangirai, won an overall majority in the election for the House of Assembly. They went on to win majorities in a large share of the local government constituencies and Tsvangirai received more votes than Mugabe in the presidential elections (“Zimbabwe, Profile-Timeline”, http://www.bbc.com/news/world-africa-14113618). Since Tsvangirai had failed to win an absolute majority, however, the two Presidential candidates were required by Zimbabwean electoral law to participate in a run off. It was in the period leading up to and during this run off that tremendous campaign of terror and violence was unleashed by the ruling ZANU-PF against the opposition MDC (Reeler, 2008). The conflict was so brutal and extensive that Tsvangirai and the MDC felt they had no recourse but to withdraw from the second election and leave Mugabe and ZANU-PF with no opposition. The result of the election was thus repudiated by all independent observers, including SADC and the AU (Reeler, 2008).

The conflict depicted was systematic, structured and state-sponsored. The Zimbabwean conflicts were examples of harsh political violence but also severe abuses of power by the Zimbabwean government. The Zimbabwean government not only abdicated its responsibility to protect its citizens but in fact, were the driving forces in driving the violent oppression into increasingly dire conditions. The sheer scale and scope of the campaign of violence are in shocking. Human Right Watch documented hundreds of cases of abductions, assaults, destruction of property and intimidation. A report of the violence in 2008 details 1798 cases of reported assaults, $75 \%$ of which was committed with the use of a weapon. 309 abductions were reported, while 109 people were obtained illegally. 420 reports of torture were made, including civilians reporting being burns with plastic bag and grass; 163 cases of falanga ${ }^{2}, 252$ fractures reported; and thousands reporting soft tissue damage ranging from haematomas to lacerations (OSISA, 2007).

The victims of much of the conflict in Zimbabwe were, with considerable evidence from a number of reports, shown to be mainly members of the opposition MDC, civil society organisations or members of the Zimbabwean Election Support Network (ZESN) (Solidarity Peace Trust, 2008). Similar reports detail that the perpetrators, or at least the alleged perpetrators were supporters of ZANU-PF and state agents. War veterans from Zimbabwean liberation war were also frequent perpetrators (Solidarity Peace Trust, 2008).

It is also clear from the conflict that occurred in 2008 that the Zimbabwean state itself, or by means of its members of government and officials, took no active measures to prevent the widespread violence. This makes the Zimbabwean state complicit and responsible for the violence due to command responsibility. Reeler argues that when evaluating a state's complicity in conflict, one need only ${ }^{2}$ Falanga is a torture technique where one is beaten on the soles of their feet. It is extremely painful, often with long term health consequences, it is often used by authorities as it leaves no visible marks of torture. 
prove that the state was either directly involved or that the state took no steps to prevent the conflict from occurring (Reeler, 2008).

\section{Impact of China's Non-Interference}

Charity Manyeruke and Shakespear Hamauswa identify three main reasons why China's role in Zimbabwe's peace process was crucial. The first is China's strategic use of its veto power in the UN Security Council. Secondly, they argue that China's own status as a developing country affords its understanding and sensitivities which Western powers are preclude from. Lastly, they highlight Chinese non-interference as a key element in the resolution for conflict in Zimbabwe (Manyeruke, Hamauswa, \& Gwiza, 2013). The root causes of many African conflicts are deeply intertwined in historical, socio-political, economic, ethnic and regional causes. Therefore, in the resolution process, it is necessarily required for one to think about security paradigms in an all-encompassing fashion. Actual peace-keeping or military intervention is not any more important than effective regional governance and sustainable post conflict peacebuilding.

After the radical implementation of the Fast Track Land Reform Program which led to widespread violence, Zimbabwe was subjected to harsh sanctions firstly by the USA and then by the EU. These actions by the USA and the EU were taken unilaterally and did not have the necessary approval from the Un Security Council (UNSC). China, afforded veto power as one of five permanent members of the UNSC, had used its very power to protect Zimbabwe from UNSC sanctions between 2000 and 2008. While the individual country sanctions imposed on Zimbabwe still had a disastrous effect, China was at least able to defend Zimbabwe from being completely dominated by Western imposed agendas (Manyeruke, Hamauswa, \& Gwiza, 2013). This not only gave Zimbabwe an opportunity to redefine itself and rebuild its democratic institutions, but it also allowed SADC the time and opportunity to play a key meditative role.

The Zimbabwean Ministry of Foreign Affairs stated that, "China has influenced how Zimbabwe implements its foreign policy through encouraging regional, political, economic and cultural cooperation with, for example its neighbours SADC and the Common Market for Easter and Southern Africa (COMESA)." (Zimbabwe Ministry of Foreign Affairs, 2011), What is important to acknowledge here is China's recognition of the importance of regional and integrated solution to conflict in Africa. Furthermore, China's understanding of the specific type of role it, as an external actor, should play while allowing those directly involved to be at the forefront of the resolution process.

From an economic point of view, Zimbabwe experienced an acceleration in Real Gross Domestic Product (GDP) from 8.1\% in 2010 to 9.3\% in 2011. This was a sharp increase from the terrible economic condition the country had been in years before when inflation had soared to over 1000\% (Zimbabwe Ministry of Foreign Affairs, 2011). Key factors of Zimbabwe's economy, such as mining and agriculture recorded significant growth rates of $57.2 \%$ and $49.8 \%$ respectively (Government of Zimbabwe, 2012). The role that China played in this economic 
turnaround cannot be underestimated. This paper referred to the role played by China as financial security. China fulfilled this role by firstly protecting Zimbabwe from further sanctions that would have been imposed by the UNSC. There is also a geopolitical stability that China offered Zimbabwe by continuing to interact economically with Zimbabwe and allowing Zimbabwe to re-enter the international arena. Raine contends that China made substantial yet discreet contributions to the post-election power sharing elections in Zimbabwe (Raine, 2009). Furthermore, China has officially financed not only humanitarian assistance but also economic development in Zimbabwe cumulating in $\$ 3.82$ billion, spanning from finances to the Zimbabwean energy sector to transport and communications as well as banking and financing services. The official finance to Zimbabwe accounts for $4.9 \%$ of all official Chinese financing to Africa. (AidData, "China's Development Finance to Africa: Version 1.0" dataset, https://www.aiddata.org/blog/peeking-behind-the-curtain-analyzing-chinese-aid -and-influence-in-zimbabwe). China, unlike other external actors, has ensured to distance itself from the constitution-making process and has resolutely abided by its policy of non-interference. Not only was China's policy of non-interference important in that it allowed Zimbabwe the space and freedom to construct its own solutions but it also played an important symbolic role. The official stance taken by China was a clear illustration to the international community that Zimbabwe's internal affairs are best attended to by Zimbabwean themselves, with the direct support of SADC. China has nevertheless been active in its diplomatic engagement with the relative parties. As evidence by the Prime Minister's delegation which visited China in 2012 to discuss Sino-Zimbabwean economic interactions, China has been willing to cooperate with all the political parties in Zimbabwe's political system.

There were two key elements to the peace process in Zimbabwe. On the one hand, SADC-with the assistance and support of the AU-played a major role in the mediation and negotiations between the conflicting parties. On the other hand, China provided much needed financial security.

\section{Analysis of the Case Study}

The case study has proven that China's non-interference policy has impacted its ability to engage in African conflicts in two fundamental ways. Initially the policy gives China immense credibility, as it is viewed to genuinely respect the sovereignty of African countries and their right to territorial integrity and self-determination. This political stance by China is vast departure from the interventionist policies of many other international powers. It not only builds and entrenches South-South cooperation but it sets a symbolic precedent to other external actors. It illustrates that African states, just like any others, ought to be treated as equals and not have their respective agendas dictated to an imposed upon them.

However, the second consequence of non-interference is more constraining and handicaps China severely. Non-interference, in its strict interpretation has 
limited China to predominantly state-centric relations. This has obstructed China's ability to be an active role player in conflict resolution as it has prevented China from engaging with vital non-state actors, particularly with the key regional organisations. Because China has not been able to fulfil a vital role in African security mechanisms, this has hampered China's ability to protect its own economic interest and foreign nationals in Africa. Furthermore, it has begun to erode China's international legitimacy as a responsible global power. This has had a subsequent negative impact on the ability for China to pursue its ideal of a "harmonious world".

China has been consistent in its strong public support for regional organisations to take the leading role in conflict resolution and mechanisms. According to Ambassador Zhang Yishang, China maintains that regional organisations hold a superior advantage in dealing with conflicts because their geographical and political positions. The Ambassador goes onto say that particularly in African context, greater support should be given to regional organisations (Zhang, 2005). Beyond this rhetorical support for the role played by African regional organisations, there doesn't seem to be much substantial cooperation between China and the relevant non-state actors. From the case study above, it is clear that China has only oved to engages outside of the spectrum of state-to-state relations when it was absolutely necessary to do so.

The case study clearly illustrated that while the policy of non-interference still serves a very important function-African states are will reeling from the effects of colonialism, so it is crucial for them to uphold their independence and protect themselves from undesired external influences-the policy is in need of a serious rethinking. The rigid manner in which the policy is presently being interpreted is incompatible with the current conditions of the African conflicts and subsequent peace processes, it not only is ineffective in terms of positively contributing to African stability, it also seriously restricts China from being able to protect its own interests and citizens in Africa.

\section{Concluding Suggestions}

The crucial question that must now be asked is how does China solve this dilemma? In other words, how can China play a more active and effective role in African security mechanisms, while abiding by its policy of non-interference? This paper suggests that there are two approaches available to China. The first involves the concepts of creative involvement and constructive intervention. These concepts need to be defined in terms of actual policy and conceptualised into actual on-the-ground strategy. This strategy should be focused on rethinking of state sovereignty to a more nuanced definition; a definition which also emphasised the responsibility states toward the protection of their populations. This rethinking will also allow China to enrich and deepen its cooperation with the African Union and the respective RECs. As Africa develops and strives towards its Pan-African idea of an integrated and united Africa, China must 
re-evaluate and reform its heavily state-centric relations with African states.

The second option available to deconstruct China-Africa relations is best captured by the theory of proxy-hegemony. This theory would involve relations between two states-or actors-in which one has an international hegemonic status while the other exerts regional hegemonic status. These two states would establish a semi-hierarchical relationship in which the global hegemon would delegate exercise of its hegemony to the regional hegemon (Moller, 2009). With regard to this particular research, China would be the global hegemon while a country such as South Africa would occupy the role of the regional hegemon.

Neither China nor South Africa has expressed hegemonic ambitions. In fact, both countries are at pains to ensure that they are not seen as power-hungry states. One could refer to these two countries as reluctant hegemons. However, the status, influence and authority that they both command in their respective geographical politico-economic spheres, are well documented.

In an attempt to find which African countries would qualify as a regional hegemon, Moller conducts a study in which he measures the distribution of capabilities of all African states. The capabilities measured include territory, population, GDP, military expenditure and armed forces. He concludes that only 10 countries have the potential to be a regional power. Out of those ten countries identified, most are disqualified as they are war-torn or have geopolitical interests elsewhere and thus would not be able to exert influence over the other states. There are, thus, only four candidates for regional hegemony left: Ethiopia, Nigeria, South Africa and Algeria (Moller, 2009). This paper explores the idea of a proxy-hegemon specifically between China and South Africa.

South Africa has been highlighted for a number of reasons. Up until very recently South Africa boasts the largest economy in Africa. It is now only second to Nigeria. South Africa plays a vital leading role in SADC, as represented by its key contributions to the resolution of the Zimbabwean conflict. Lastly, South Africa offers a certain stability, level of development and international status that other African countries lack. South Africa also played a central role in the reform of the OAU to the AU. NEPAD and the APRM were driven resolutely by President Mbeki and invested heavily in by South Africa. It is moreover put forward that China and South Africa have cooperated in tandem in the UNSC to bring attention to peacekeeping initiatives in Africa. South Africa's determination to pursue and partake in regional infrastructure development corresponds directly to China's approach to Africa. This can be witnessed in China's contribution to regional public goods such as intra and inter-stat railway projects (Moller, 2009).

What South Africa and its curiously close ties present China with as a means with which to protect its interests in Africa without appearing to interfere in the internal affairs of other states. South Africa, as a regional authority and key player in SADC and the AU, provides a security getaway for China. In return, South Africa receives delegated hegemonic status and all the subsequent benefits. To date, those benefits have included a rapid rise and improvement in Sino-South 
African relations. China is not South Africa's largest trading partner, having overtaken the States in 2009 (BRICS, 2014). This noteworthy development of Sino-South Africa relations came to fruition with South Africa being invited to join the then-BRIC (Brazil, Russia, India and China) country coalition. A significant share of the credit for South Africa's entry into BRICS must go to China as it promoted and supported the idea ardently (Alden \& Wu, 2014).

Through cooperation in regional peace initiatives led by South Africa through SADC and the AU; aligned decision-making at the UNSCH; the establishment of alternative governance and development institutions such as the BRICS Development Bank; China and South Africa have the potential to be heralded as leaders of the Global South.

\section{Conflicts of Interest}

The author declares no conflicts of interest regarding the publication of this paper.

\section{References}

Alden, C., \& Large, D. (2011). China's Exceptionalism and the Challenges of Delivering Difference in Africa. Journal of Contemporary China, 20, 21-38. https://doi.org/10.1080/10670564.2011.520844

Alden, C., \& Large, D. (2015). On Becoming a Norms Maker: Chinese Foreign Policy, Norms Evolution and the Challenges of Security in Africa. The China Quarterly, 221, 123-142. https://doi.org/10.1017/S0305741015000028

Alden, C., \& Wu, Y. (2014). South Africa and China: The Making of a Partnership. Global Powers and Africa Programme, Occasional Paper 199.

Askouri, A. (2007). China's Investment in Sudan: Displacing Villages and Destroying Communities. In F. Manji, \& S. Marks (Eds.), African Perspectives on China in Africa (pp. 71-86). Cape Town: Fahamu-Networks for Social Justice.

Beijing Review. New Directions for China's Diplomacy. March 5, 2012. http://www.bjreview.com.cn/world/txt/2012-03/05/content_439626_2.htm

Berhe, M. G., \& Liu, H. (2013). China-Africa Relations: Governance, Peace and Security. Addis Ababa: South African Institute for Peace and Security Studies.

BRICS (2014). Join Statistical Publication. Rio de Janeiro: Institutio Brasileiro de Geografia Estatistica. https://brics.ibge.gov.br/downloads/BRICS_Joint_Statistical_Publication_2014.pdf

Cornelissen, S., \& Taylor, I. (2000). The Political Economy of China and Japan's Relationship with Africa: A Comparative Perspective. The Pacific Review, 13, 615-633. https://doi.org/10.1080/095127400455350

Gill, B. K. (1993). Hegemonic Transitions in the World Systems. In A. G. Frank, \& B. K. Gill (Eds.), The World System. Five Hundred Years or Five Thousand (p. 97)? London: Routhledge.

Government of Zimbabwe (2012). The 2013 National Budget Statement. Harare: Ministry of Finance, Government of Zimbabwe.

He, W. (2006). China-Africa Relations Moving into an Era of Rapid Development. Inside AISA, No. $3 \& 4,3-6$.

He, W. (2007). “All Weather Friend”: The Evolution of China’s African Policy. In K. K. 
Prah (Ed.), Afro-Chinese Relations: Past, Present and Future (pp. 24-47). Cape Town: CASAS.

He, W. (2008). China's Perspectives on Contemporary China-Africa Relations. In C. Alden, D. Large, \& R. S. de Oliveira (Eds.), China Returns to Africa: A Superpower and a Continent Embrace. London: C. Hurst.

He, W. (2009). China's African Policy: Driving Forces, Features and Global Impact. Africa Review, 1, 35-53. https://doi.org/10.1080/09744053.2009.10597279

He, W. (2010). China's Aid to Africa: Policy Evolution, Characteristics and Its Role. In J. S. Sense (Ed.), Challenging the Aid Paradigm: Western Currents and Asian Alternatives (p. 10). Houndmills: Palgrave Macmillan.

Human Rights Watch (2002). Fast Track Land Reform in Zimbabwe. African Division.

Kambudzi, A. M. (2013). Africa and China's Non-Interference Policy: Towards Peace Enhancement in Africa. Addis Ababa: South African Institute for Peace and Security Studies.

Keohane, R. (1982). The Demand for International Regimes. International Organization, 36, 325-355. https://doi.org/10.1017/S002081830001897X

Keohane, R. O. (1996). The Theory of Hegemonic Stability and Changes in International Economic Regimes, 1967-1977. In C. R. Goddard, J. T. Passé-Smith, \& J. G. Conklin (Eds.), International Political Economy: State-Market Relations in the Changing Global Order (64-84). Boulder, CO: Lynne Rienner Publishers. https://doi.org/10.1007/978-1-349-24443-0_8

Kuo, S. C. Y. (2012). Beijing's Understanding of African Security: Context and Limitations. African Security, 5, 24-43. https://doi.org/10.1080/19392206.2012.653306

Large, D. (2008). Beyond "Dragon in the Bush": The Study of China-Africa Relations. African Affairs, 107, 45-61. https://doi.org/10.1093/afraf/adm069

Li, A. (2005). African Studies in China in the Twentieth Century: A Historiographical Survey. African Studies Review, 48, 59-87. https://doi.org/10.1353/arw.2005.0002

Li, A. (2007). China and Africa: Policies and Challenges. China Security, 3, 68-94.

Li, A. (2011). Cultural Heritage and China's Africa Policy. In J. Men, \& B. Barton (Eds.), China and the European Union in Africa (pp. 41-59). Farnham: Ashgate.

https://doi.org/10.4324/9781315571621-3

Liu, H. (2008). China-Africa Relations through the Prism of Culture: The Dynamics of China's African Cultural Diplomacy with Africa. Journal of Current Chinese Affairs, 37, 10-45.

Liu, H. (2010). China's Development Cooperation with Africa: Historical and Cultural Perspectives. In Cheru, \& Obi (Eds.), The Rise of China and India in Africa (p. 56, p. 78). London: Zed Book.

Lu, S. (2013). Reflections of a New Kind of China-Africa Relations. Zhejiang: Institute of African Studies Zhejiang Normal University. http://ias.zjnu.cn/show.php?id=2627

Manyeruke, C., Hamauswa, S., \& Gwiza, A. (2013). China: A Critical Factor in Zimbabwe's Crisis and Its Solutions. In China-Africa Relations: Governance, Peace and Security (195-208). Cape Town: South African Institute for Peace and Security Studies.

Moller, B. (2009). The African Union as Security Actos: African Solutions to African Problems? In Regional and Global Axes of Conflict (p. 3). Working Paper No. 57, London: Crisis States Research Centre.

OSISA (2007). We Have Degrees in Violence: A Report on Torture and Human Rights Abuses in Zimbabwe. A Report by the Open Society Initiative for Southern Africa, The 
Open Society Institute \& The Bellevue/NYU Program for Supervisors of Torture, Johannesburg: Open Society for Southern Africa.

Oxford Pro Bono Publico Group (2005). Are the Activities Conducted During Operation Murambatsvina Crimes against Humanity within the Meaning of Article 7 of the Rome Statute? International Law Opinion: University of Oxford.

Pan, H. (2011). China's Soft Power in Africa. The African Executive, November 2-9. https://www.africanexecutive.com/article.php?section_id=12\%20\&\&\%20article_id=\%2 $\underline{06184}$

Raine, S. (2009). China's African Challenges. Adelphi Series, Abingdon-on-Thames: Routhlede.

Reeler, T. (2008). Subliminal Terror? Human Rights Violations and Torture in Zimbabwe during 2008. Johannesburg: Centre for Study of Violence and Reconciliation.

Shi, Y. (2008). China's Peaceful Development, Harmonious World and International Responsibility: Achievements and Challenges. SIIS Global Review, Spring 2008, 25-26.

Solidarity Peace Trust (2008). Punishing Dissent, Silencing Citizens: The Zimbabwean Elections 2008. 21 May 2008, Solidarity Peace Trust.

Speers-Mears, E. (2011). China's Growing Role in African Peace and Security. London: Saferworld.

The Description of the 12th CPC Assembly. http://www.people.com.cn/GB/shizheng/252/5089/5104/5276/20010429/467489.html

The Economist. More than Minerals. May 23, 2013. http://www.economist.com/news/middle-east-and-africa/21574012-chinese-trade-afric a-keeps-growing-fears-neocolonialism-are-overdone-more

UN Habitat (2005). Report of the Fact-Finding Mission to Zimbabwe to Assess the Scope and Impact of Operation Murambatswina by the UN Special Envoy on Human Settlements Issues in Zimbabwe.

Yu, J., \& Wang, Z. (2008). China-Africa Strategic Partnership Ushered in a New Era. In China-Europe-Africa Co-Operation: Chances and Challenges: Proceedings of the 6th Shanghai Workshop on Global Governance (pp. 77-105).

Yu, S. (2014). Africa in China's Foreign Policy. Washington DC: Brookings.

Zhang, Y. (2005). Special Committee on Peacekeeping Operations, Permanent Mission of the People's Republic of China to the UN.

http://www.china-un.org/eng/zghlhg/hphaq/whxd/t182269.htm

Zimbabwe Ministry of Foreign Affairs (2011). Zimbabwe's Foreign Policy. http://www.zimfa.gov.zw/index.php/foreign-policy

Zimbabwe, Profile-Timeline. http://www.bbc.com/news/world-africa-14113618 